See discussions, stats, and author profiles for this publication at: https://www.researchgate.net/publication/325539738

\title{
The multimedia development for learning writing
}

Conference Paper · January 2018

DOI: $10.29210 / 2018155$

CITATIONS

0

3 authors, including:

Atmazaki Atmazaki

Situs Resmi Universitas Negeri Padang

15 PUBLICATIONS 8 CITATIONS

SEE PROFILE

Some of the authors of this publication are also working on these related projects:

The development of digital-based authentic assessment in Indonesian Language View project 


\title{
The multimedia development for learning writing
}

\author{
Lusia Oktri Wini ${ }^{1}$, Atmazaki $^{2}$, Novia Juita ${ }^{3}$ \\ ${ }^{123}$ Universitas Negeri Padang, Padang - Indonesia, (lusia.wini@gmail.com)
}

\begin{abstract}
This study aims to produce a multimedia learning narrative writing that is valid, practical, and effective for use by students. This type of research is a development study, which develops multimedia learning using the $4 \mathrm{D}$ development model that begins with the defining, designing, developing, and deploying stages. Instruments used in this study are questionnaires, observation sheets, and performance tests. Based on the results of data analysis and discussion can be concluded as follows. First, the validity of developed multimedia is quite valid that is the percentage $82.63 \%$. Second, the developed multimedia practicability is very practical with the percentage of $81.75 \%$. Third, the effectiveness of multimedia developed is effective with the percentage of $78,72 \%$ with 49 people from 51 students from two test schools reaching value above the national standardization. Thus, the multimedia that has been developed can be used as a teaching medium in learning Indonesian especially narrative writing materials.
\end{abstract}

Keyword: multimedia development, learning writing

This is an open access article distributed under the Creative Commons 4.0 Attribution License, which permits unrestricted use,

\section{Introduction}

Writing and thinking are interrelated. Writing is a complex process that allows writers to explore thoughts and ideas, and make them concrete. Thinking is the basis for writing and thinking is central to learning. Students can make their mind proceed concretely through writing (Atmazaki, 2007: 3). So, with the writing activity, students can be encouraged to be creative in thinking. According to Graham, et al (2012: 6) "The students who develop strong writing skills at an early age acquire a valuable tool for learning, communication, selfexpression, and help them succed in school and society". This opinion suggests that students who develop strong writing skills at an early age obtain valuable tools for learning, communicating, expressing themselves, helping them succeed in school and society.

As the research conducted by Lubis, et al (2015: 17) below. Another fact that states that writing ability is low is known from the teaching materials used by teachers and students still based on textbooks, the book is the only source of information for learning. All learning materials written and even notes for students come from textbooks. Teachers are not trying to create new teaching materials to improve students' understanding and learning outcomes. The 
difficulties of understanding the writing materials are perceived by the students, the students do not understand what the opening, discussion, and closing parts are

In addition to teachers, other learning resources that students use are textbooks. However, as the times progressed, students rarely read books, they were more interested in reading in digital media. With a more colorful look, moving pictures, and accompanied by background music are the main attraction of reading in digital media, so students do not get tired of learning and reading. Though writing skill refers to the importance of the power of hearing and reading. This is supported by the opinion of Muhammad Ali (2009) in his development journal stating that, "Knowledge and skills, attitude and behavior change can occur because of the interaction between new experiences and experiences experienced before." Based on that opinion, the use of appropriate and diverse media can add to the knowledge and explore the skills of the students.

To overcome these problems, one of the efforts that can help students in obtaining better learning outcomes is by using multimedia learning. Use of multimedia learning in the learning process requires remembering habits, which will facilitate students in constructing or building knowledge, its usefulness is very effective to achieve learning objectives. According to Sethi (2005); Mayer (2001), "Multimedia refers to the integration of two or more different information media within a computer system. These arguments say multimedia refers to the integration of two or more different information media in a computer system. This medium can include text, images, audio, and animations. Vaughan (2011), defines multimedia as a combination of digitally manipulated text, images, graphic arts, sound, animation, and video elements. so, it can be said that multimedia as a combination of text, graphics, sound, animation, and video delivered by some form of computer. When the user has control of what is presented it becomes an interactive multimedia.

Research conducted by Mbarika et al. (2010) states "Indicating that multimedia learning has an important role in improving (enhancing) the learners' learning experience, a higher understanding of problem solving and or attitudes toward teaching." This study shows that multimedia learning havean important role in improving learning learning experience, higher. to speak items.

This research was conducted to determine the validity, effectiveness, and practicality of multimedia learning that has been developed. Multimedia learning, multimedia learning, instructional media, multimedia learning, multimedia learning. In addition, the effectiveness of multimedia learning will increase if in the process and making it pay. Therefore, a study entitled "Multimedia Development of Narrative Textbook Writing for Junior High School Grade VII" is important to implement.

\section{Method}

The type of this research is development research, because it develops a learning device. Learning tools developed in the form of multimedia learning Indonesian subject of narrative writing. Research and development method is a research method used to produce a specific product and test the effectiveness of the product (Sugiyono, 2009; Trianto, 2010). Research development begins by looking at the problems that arise in the learning process in schools, then think of an attempt to overcome the problem of efforts to develop a learning product that is expected to help teachers and students. The resulting product is validated first by an expert using an expert validation questionnaire. In addition, it is necessary to know also the practicality and effectiveness of products developed so that it can be done revision until it is really feasible to use (Ary, et al., 2000) 
The study was conducted in two schools, namely SMP 1 Kubung and SMP 2 Gunung Talang, Solok District, two different schools of this district are considered to represent the existing high schools in Solok District, in addition, researchers have conducted research in these two schools before, knowing the development of schools, also received good support from the environment of both schools. There were 51 students in the pilot study, with 25 people from SMK 1 Kubung, and 26 from SMP 2 Gunung Talang. Instruments used in this study are questionnaires, observation sheets, and performance tests.

The development model used is the development model suggested by Thiagarajan et al., The 4 -D model. The product developed in this research is multimedia learning. The 4-D development model consists of four developmental stages: define, design, develop, and desseminate. Data analysis technique used is descriptive data analysis, by describing the validity, practicality and effectiveness of learning multimedia stored in the pieces of Compact Disc (CD). First, the validation analysis by the expert / expert. The results of multimedia validation by experts were analyzed using descriptive statistics. Second, the analysis of multimedia practicability is analyzed using a questionnaire instrument filled by teacher and student trials. Third, the effectiveness analysis. The data source of multimedia effectiveness comes from student activities during learning through multimedia narrative writing, and performance test results are given after learning multimedia writing narrative.

\section{Result}

This development research produces a teaching material in the form of multimedia learning narrative writing. The design or the developed multimedia design has been adapted to the multimedia-making structure in Depdiknas (2008). To get quality multimedia, then the required validity, practicality, and effectiveness of the multimedia. Validation is very important to know the quality of multimedia before being piloted in learning. In addition, validation is very important to get an assessment of the multimedia draft that has been compiled. This is in accordance with the opinion of Daryanto (2013: 22) which states that the validation is a process to test the suitability of multimedia with the competencies that become learning objectives. If the content of multimedia is appropriate, it means effective to learn the competencies that become learning objectives, then the multimedia declared valid. In this Result, we just discussion about the effective of multimedia writing and discussion with previous research.

\section{Effectiveness of Multimedia Writing}

The results of effectiveness sourced from the observer observation of student activities during learning multimedia writing narration, and student learning outcomes of the test given after learning multimedia writing narration. For more details, both of these will be explained below. (a) Student activity. During the learning process using multimedia narrative writing, student activity is always observed. Activity indicator which is the target of observation is 5 activities. The five activities of the indicators are described as follows. First, listen to the teacher's instruction on how to use multimedia learning. Second, study the material that is in the multimedia as well as doing things that are relevant to the learning materials. Third, follow the instructions for using and running multimedia. Fourth, do the understanding test and the exercises in multimedia. Fifth, stay calm and focus with the computer device without disturbing other students.

Based on the results of questionnaire observation analysis, obtained the result that in general, student activity is very active or very successful. Based on the results of student activity analysis, it can be concluded that multimedia writing narration is very effective with the average value of activity of 96.86 with criteria very tinngi and success rate is very successful. 
Thus, multimedia narrative writing can be used in narrative narrative learning in particular, and Indonesian language learning in general.Student learning outcomes in learning narrative writing materials can be seen from the tests given to the students. Based on the analysis of the results of the score analysis and test scores for the work, the conclusion is that the students of the test class are generally in the Excellent Well (BS) qualification with an average value of 78.72. The average value has been fulfilled thoroughness in learning multimedia writing narration that is $>78$. The number increases from the value of writing a student narrative before using multimedia which only reaches an average of 77.64 .

Overall, the value of students in learning multimedia writing narratives can be described as follows. First, the students who get the value of 86-95 qualified very well amounted to 5 people. Second, Students who get a score of 76-85 qualified well with the number of 42 people. Third, Students who got 66-75 qualified more than enough amounted to 4 people.After validity test, practicality test, and effectiveness test are described, it can be argued that multimedia writing narration included in the category is very valid because the validity value is $82.63 \%$. Multimedia writes practical narratives because the value of multimedia practicality of writing narration by the teacher of $88.98 \%$, and the value of the practicality of multimedia writing narration by students of $81.75 \%$.

Then, multimedia writing narratives are said to be effective because the value of student learning outcomes performs the average performance test of 78.72 in both qualifications and the highest value of 88.5 and the lowest is 74.5. It means that teachers and students can use multimedia narrative writing on specific narrative writing lessons, and Indonesian language learning in general. The overall conclusion is based on the opinion of Riduwan (2012: 15) which states that the values that are at intervals of 61-80 are valid and practical. Meanwhile, Nurgiyantoro (2001: 400) suggests that the value of students who categorized well is at the level of mastery of 76-85.

\section{Discussion with Previous Research}

The results of previous studies which stated that good multimedia use in learning, are acceptable. so, a comprehensive multimedia can be used as a medium of teaching in learning Indonesian particularly narrative writing material. This feasibility study can add multimedia instructional media types for Bahasa Indonesia subject.

\section{Conclusions}

Based on the results of research and discussion, it can be concluded research results as follows. The multimedia learning narrative writing developed is effective. The process of developing effective multimedia learning narrative writing is known by analyzing data on learning outcomes and student activities. Based on the learning outcomes of students in grade VII in SMP Negeri 1 Kubung, obtained grade average grade 79.90 which is in good qualification. The results of studying students in grade VII in SMP Negeri 2 Gunung Talang, obtained an average grade grade of 77.54 which is in good qualification. Based on the analysis obtained from the average of the students both test schools reached 78.72 with good category.So, multimedia can be used as a medium of teaching in learning Indonesian particularly narrative writing material. This feasibility study can add multimedia instructional media types for Bahasa Indonesia.

Based on the conclusions of this study, then got suggestions in accordance with the results of research as follows. First, the principal should suggest that teachers create their own teaching media that conforms to the characteristics of students for learning to make learning more meaningful. Secondly, teachers should use multimedia writing this narrative and can increase 
student activity and learning outcomes. Third, students should use multimedia narrative writing that has been developed in the learning, following the instructions and work steps that exist in multimedia narrative writing. Fourth, the next researcher, can use the results of this study as relevant research and if you want to develop a teaching medium, develop the media wrote with different materials.

\section{Acknowledgments}

In the implementation of research and preparation of this article, the authors get a lot of help and guidance from various parties. On this occasion the author would like to thank sincerely to: Prof. Dr. Atmazaki, M.Pd As Advisor I and Dr. Novia Juita, M.Hum As Advisor II, and the Examiner: Prof. Dr. Syahrul R. M.Pd, Dr. Erizal Gani, M.Pd, Dr. Afnita, M.Pd, and Prof. Dr. Azwar Ananda, MA

\section{References}

Ali, M. (2009). Pengembangan Media Pembelajaran Interaktif. (http://journal.uny.ac.id /index.php/-. jee/article/download/348/250).

Arikunto. (2007). ProsedurPenelitian (SuatuPendekatanPraktik). Jakarta: PT RinekaCipta.

Ary, Donald., Jakobs, L.c., and Razavieh, A. (2000). "Penelitian dalam Pendidikan". Terjemahan Arief Furchan. Surabaya: Usaha Nasional.

Atmazaki.

“PengembanganKeterampilanMenulissebagaiUpayaPencerdasanSiswa".Padang.

Clark, Richard. E. (2008). Media Will Never Influence Learning. ETRED Educational Technology Research and Development, 42(2), 21-29.

Graham, s., dkk. (2012). Teaching elementary School Students to be Effective Writers: a Practice Guide. NCEE 2012-4058. What Works Clearinghouse.

Ivers, K.S \& Barron, A.E. (2010). Multimedia Projects in Education: Designing, Producing, and Assessing. Fourth Edition. Santa Barbara, California: Libraries Unlimited.

Lubis, M. S., dkk. (2015). Pengembangan modul pembelajaran Bahasa Indonesia berbantuan peta pikiran pada materi menulis makalah siswa kelas XI SMA/MA. Jurnal Bahasa, Sastra dan Pembelajaran UNP.Vol. 2. No. 1. pp 16-28

Mayer, R. E. (2001). Multimedia learning, Cambridge: Cambridge University Press, ch. 1, pp. $2-$ 3.

Mbarika,V., Bagarukayo,E., Shipps,B.P., Hingorani,V., Stokes,S., Kourouma,M. \& Sankar, C.S. (2010). "A MultiExperimental Study on the Use of Multimedia Instructional Materials to Teach Technical Subjects". Journal of STEM Education; Special Edition on 2010; 24-37.

Riduwan.(2012). Skala pengukuran variabel-variabel penelitian. Bandung: Alfabeta.

Sugiyono. (2009). MetodePenelitian Pendidikan: PendekatanKualitatif, Kuantitatif, dan RED. Bandung: Alfabeta.

Thiagarajan, S., Semmel, D.S \&Semmel, M.I. 1974. Instructional Development for Training Teachers of Expectional Children. E-book. (online), (www.eric.edu.gov) diakses 1 September 2015.

Trianto. (2010).Model pembelajaran terpadu. Jakarta: Bumi Aksara.

Vaughan, T. (2011). Multimedia: Making It Works. 8th Edition. New York: McGraw Hill, 2011. 